\title{
Distribution and biogeography of Bactrocera and Dacus species (Diptera: Tephritidae) in Papua New Guinea
}

Anthony Clarke ${ }^{1}$, Solomon Balagawi ${ }^{2,3}$, Barbara Clifford ${ }^{3}$, Richard A.I. Drew ${ }^{3}$, Luc

Leblanc $^{4}$, Amanda Mararuai ${ }^{2}$, Daniel McGuire ${ }^{3}$, David Putulan $^{2}$, Travis Romig $^{3}$, Sim Sar $^{2}$ and David Tenakanai ${ }^{5}$

1. School of Natural Resource Sciences, Queensland University of Technology, GPO Box 2434, Brisbane, Queensland 4001, Australia.

2. National Agricultural Research Institute, P.O. Box 4415, Lae 411, Morobe Province, Papua New Guinea.

3. Australian School of Environmental Studies, Griffith University, Nathan, Qld 4111, Australia.

4. SPC Project on Pest Management in the Pacific - Fruit Fly Management, Secretariat of the Pacific Community, Private Mail Bag, Suva, Fiji.

5. National Agricultural \& Quarantine Inspection Authority, P.O. Box 714, Port Moresby, National Capital District, Papua New Guinea. 


\begin{abstract}
Based on literature records and the results of an extensive trapping program, presence records for 194 species of Bactrocera and Dacus in the 19 provinces of Papua New Guinea are presented: of the 770 records over 500 are new. Based on species accumulation curves, Central, Morobe, Madang, Eastern Highlands, Western Highlands, New Ireland and Bougainville provinces, plus the province pairs of East and West Sepik, East and West New Britain, and Southern Highlands and Enga, can be regarded as having been adequately sampled. The remaining provinces should still be regarded as being under-collected. On mainland PNG, Morobe and Central provinces have the richest faunas and highest levels of endemism, approximately $15 \%$ each. All other mainland provinces have very low levels of endemism and are essentially subsets of the faunas of Morobe and Central Province. Although also with very low levels of endemism, the Highlands provinces have a statistically distinct fauna, suggesting that a pool of the PNG species are able to utilise both lowland and highland habitats. The fruit fly fauna of the island provinces is distinct from the mainland fauna, with further separation between the islands of the Bismark Archipelago (New Britain and New Ireland) and Bougainville. The greatest diversity of flies in PNG are associated with major northern geological elements, ie the New Guinea orogen, New Guinea accreted terranes and the off-shore islands, rather than the primary southern geological element, the Australian creton.
\end{abstract}




\section{Introduction}

The dacine fruit fly (Diptera: Tephritidae: Dacinae) fauna of Papua New Guinea (PNG) is extremely rich, with over 190 described species in the genera Bactrocera Macquart and Dacus Fabricius (Drew 1989; Drew \& Romig 2001). As in neighbouring countries, fruit flies are considered major pests of agriculture (Waterhouse 1997), with 18 species having some level of pest status (Leblanc et al. 2001). Approximately $75 \%$ of species are endemic, with the remainder largely restricted to West Papua (formerly Irian Jaya), the Solomon Islands, Torres Strait and far north Queensland. It is probable that many more PNG species occur in West Papua, but the western half of the island of New Guinea has been very poorly surveyed for fruit flies (White \& Evenhuis 1999).

The taxonomy of the Papua New Guinea fruit flies is considered relatively well known, due largely to the work of Drew (1989) and Drew and Romig (2001). However, the distribution of the species is less well known. In Drew's (1989) monograph there is a general paucity of locality data, with the majority of species known from only one or two localities. Fletcher (1998) supplemented this information with a collection of over 50 species from lowland forest in Madang Province, but this still left large parts of the country inadequately surveyed. Understanding the distribution of fruit flies in PNG is not only important in the context of economic entomology, but has wider implications for understanding faunal and floral biodiversity patterns within PNG (Heads 2001b, 2001c, 2002a, 2002b) and the region (Michaux 1994; Michaux \& White 1999).

As part of a larger project (the PNG Fruit Fly Project [PNGFFP], see Acknowledgements), we undertook the first near nation-wide survey of PNG's fruit fly fauna to determine the distribution of the country's species. This paper presents the results of that survey, as well as a collation of previously published information. 


\section{Materials and Methods}

\section{Distribution data}

Distribution data was accumulated from previously published records (Drew 1989; Fletcher 1998; Drew \& Romig 2001), plus extensive new collections made as part of the PNGFFP.

Fruit flies were collected from June 1998 to September 2001 using, in total, 167 pairs of cue-lure- and ME-baited modified Steiner traps (White \& Elson-Harris 1992; Leblanc et al. 2001). Traps were hung, wherever possible, in fruit fly host trees at approximately $1.8 \mathrm{~m}$ above the ground and were cleared of flies every 2-3 weeks. Samples were subsequently forwarded to Griffith University, Brisbane, where they were identified to species using the keys in Drew (1989). Drew carried out confirmation of species. All provinces of PNG were sampled with the exception of Gulf and Oro (= Northern) provinces: distribution records for these provinces are based on the literature. Due to logistic constraints some provinces were sampled extensively (eg Central, Morobe and East New Britain), while others were only poorly sampled (eg Western and Milne Bay) (Table 1). Not all traps ran the full length of project and some were in place for as few as two to three months. The survey covered four of the five broad agro-ecological zones recognised by the [PNG] National Agricultural Research Institute, viz. Dry-lowlands, Wet-lowlands [Mainland], Wetlowlands [Islands] and Highlands (1200-2000m asl). The Dry-lowlands are typified by savanna and open-woodland; the Wet-lowlands (both mainland and islands) are typified by closed tropical rainforests; while the Highlands consist of subtropical/temperate grasslands in valleys surrounded by high altitude rainforests. The fifth region, High-altitude Highlands, was not sampled because few agricultural plants occur above altitudes of 1800m (NARI internal documentation) and sampling this region was considered of low priority to the PNGFFP. Given the absence of a specialist Highlands fruit fly fauna (see Results), it appears unlikely that sampling in the High-altitude Highlands would have added many (if any) new provincial records.

\section{Presentation and Analysis}

Distributions are presented as presence in a province: abundance data is not presented because of unequal sampling effort. Provinces are the major internal political units of 
PNG (Fig 1). Although not ideal to restrict distributions to political boundaries, logistic and access constraints made it impossible to sample in any transect type pattern that would subsequently allow the estimation of true biological distributions. Fortunately, PNG provincial boundaries commonly match biogeographic boundaries, such as the islands (Manus, New Ireland, Bougainville, East and West New Britain), highlands (Eastern, Western and Southern Highlands, Enga, Chimbu) and lowland mainland (remainder), allowing some broad biogeographical inferences to be drawn. In three cases we combined neighbouring provinces for biogeographic analysis so as to have one higher quality data set, rather than two lesser quality sets. Our underlying assumption in combining the provinces was that each province pair (East New Britain and West New Britain [referred to hereafter as New Britain]; East Sepik and West Sepik [Sepik]; and Southern Highlands and Enga [SthHigh/Enga]) belonged to the same biogeographic region and would have very similar faunas. Subsequent analysis (see results) suggests that this assumption was probably valid.

To compare species distributions across provinces, we first generated species accumulation curves (=collectors' curves) for each province/province-pair to determine how effective collecting had been. If the accumulation curves were beginning to flatten, as demonstrated by their fit to a logistic regression, we made the assumption that a high percentage of the local fauna had been trapped and we included the province in subsequent comparisons. If the accumulation curves showed no signs of flattening we assumed that collections were incomplete and excluded the province, so that any further analysis was not unduly biased. Subsequent analysis included: determining the number of species endemic to a single province; determining the number of species shared between provinces; calculating the Sorensen incidence-based similarity index between provinces; and a hierarchical average linkage cluster analysis (Gauch 1982; Magurran 1988). The number of shared species and Sorensen's index were calculated using EstimateS Vs 6 (Colwell 2001), while the cluster analysis was done on Systat Vs 8.0 (Systat-Products 1998). We did not generate collectors' curves for Oro (0 samples), Gulf (0 samples), Milne Bay (4 samples) and Western (5 samples) Provinces. Clearly these provinces require further sampling to develop good estimates of their fauna. 


\section{Results}

Seven-hundred and seventy positive collection records are provided for 194 species across the 19 provinces of PNG (Appendix 1), approximately 520 more than previously known. Over 70 species are still known only from a single province, although these endemics generally constitute less than $15 \%$ of a provincial fauna. Bougainville is exceptional in this regard, with $50 \%$ of its 24 species not known from elsewhere in PNG (Table 1). Relatively few species are widely spread, with only 16 species $(8 \%)$ being found in more than 10 provinces. Nine of these 16 are minor or major pest species (Leblanc et al. 2001). The most widely distributed non-pest species are B. chorista (May), B. fulvicauda (Perkins), B. recurrens (Hering), $B$. seguyi (Hering) and B. vulgaris (Drew).

\section{Faunal patterns}

Species accumulation curves suggest that of those provinces (or province-pairs) analysed, most had been adequately sampled, with the species accumulation curves reaching asymptotes (Fig 2). Chimbu and Manus do not fall into this category as there were no obvious asymptotes in their curves: linear regressions explained the pattern of new species collection as well or better than sigmoid regressions for these two species. We therefore excluded Chimbu and Manus from subsequent across province comparisons on the assumption that they were under-sampled. Although collectors curves reached asymptotes, we note a significant correlation $(r=0.61, p<$ 0.01 ) between the number of trap sites within a province and the total number of species recorded for that province (Table 1). This suggests that if we had increased the number of trap sites in some or all provinces (rather than continuing to trap at the same sites) new species may well have been detected. When presenting and interpreting biogeographic patterns, this limitation must be kept in mind.

Hierarchical cluster analysis showed distinct clusters based on biogeographic regions (Fig 3). New Britain and New Ireland (islands of the Bismark Archipelago) had very similar faunas (Table 2) and were more closely related to the Bougainville fauna than the mainland fauna (Fig 3). The highland provinces formed a recognisable cluster, although they have very few endemic species (Table 1). It appears that while few fruit fly species are specifically adapted to higher altitudes, a larger but restricted 
number can utilise both high and low altitude sites. We note here a generally low abundance of many fruit fly species in the highlands (unpublished data), suggesting that there may be a large migrant fauna, or at most only limited, seasonal populations. Bactrocera (Zeugodacus) daula Drew was the only species widespread across the highlands but absent from other regions of PNG. The Madang and Sepik faunas had high levels of similarity (Table 2), or conversely low levels of dissimilarity (Fig 3), and can probably be regarded as constituting a single fauna. Again, there were very few species endemic to these provinces (Table 1).

Central and Morobe Provinces had the richest faunas, with a comparatively high level of provincial endemics, although this may reflect the sampling effort in these provinces (Table 1). The degree of similarity between Central and Morobe was high, with 69 shared species and a similarity index of 0.68 (Table 2).

\section{Discussion}

The fruit fly fauna of PNG is extremely rich, with 194 described species. With the publication of this paper, provincial faunas can now be considered well documented for all provinces except Western, Gulf, Milne Bay, Oro, Chimbu and Manus, which are probably still under sampled.

Heads (2001a, 2001b, 2001c, 2002a, 2002b) has recently published a series of papers on the biogeography of New Guinean fauna and flora, with particular respect to the island's geological history. In most cases, patterns of regional diversity can be associated with one of three major geological attributes, the Australian craton, the New Guinea orogon (= Cainozoic volcanic arcs) and the accreted New Guinea terranes (see Fig 1 in Heads 2001c). Apparent centres of diversity for PNG fruit flies, Morobe and Central Provinces (Table 1), fall within areas of the New Guinea orogon and accreted terranes, outward of the Australian craton. Three genera of cicadas (Cosmopsaltria Stål, Gymnotympana Stål, Papuapsaltria De Boer) (Heads 2002b), tiger beetles (Miller et al. 1993 cited in Heads 2002b) and butterflies (Parsons 1999) also have centres of diversity above these underlying geological features. The level of our data presentation and the obvious dispersion by the fruit fly fauna to other parts of the island makes more accurate association of the fly fauna with New Guinea's 
geological history impossible. Nevertheless, the highly accreted nature of much of New Guinea's geology (see discussion of relevant geological papers in Heads 2002a) may help explain the high level of speciation that has obviously occurred on this relatively small, and geologically new, landmass.

Michaux and White (1999), in a biogeographic analysis of the Pacific Dacinae, group the Australian, PNG and Solomon Islands fauna into a single biogeographic unit (described by them as the 'cratonic margin'). This analysis tends to gloss over the quite different faunas between Australia, mainland PNG and the PNG islands. Cluster analysis shows the island fauna as having a high level of dissimilarity to the mainland fauna, while within the island provinces Bougainville is quite distinct (Fig 3 and Table 2) and is biogeographically linked with the Solomon Islands fauna (Drew \& Romig 2001). The islands of the Bismark and Solomon Archipelagos are geologically unrelated to the Australian craton, although they are related to the accreted terranes of New Guinea's north (Hall 2001). Docking of island accretions from the northern Pacific with the Australian craton over the last 40 million years to form the island of New Guinea (Polhemus \& Polhemus 1998; Hall 2001), appears to have led to a diverse, but relatively uniform fruit fly fauna over the PNG mainland, albeit with one or two areas of higher local endemism (Table 1). In contrast, the islands of the neighbouring archipelagos have remained geologically separate and retain a distinct fauna with high levels of endemism.

\section{Acknowledgements}

This work was undertaken as part of the PNG Fruit Fly Project. This project was jointly funded by the Government of Papua New Guinea, FAO/AusAID/UNDP/SPC Project RAS/97/331 (Regional Management of Fruit Flies in the Pacific) and ACIAR/AusAID Project CS2/1996/225 (Identification, biology, management and quarantine systems for fruit flies in Papua New Guinea). We thank the many volunteers who allowed us to hang traps on their properties and who serviced the traps. 


\section{References}

Colwell RK. 2001. EstimateS: Statistical estimation of species richness and shared species from samples. Version 6.0b1. Users guide and application published at, http://viceroy.eeb.uconn.edu/estimates.

Drew RAI. 1989. The tropical fruit flies (Diptera: Tephritidae: Dacinae) of the Australasian and Oceanian regions. Memoirs of the Queensland Museum 26, $1-521$.

Drew RAI \& Romig MC. 2001. The fruit fly fauna (Diptera: Tephritidae: Dacinae) of Bougainville, the Solomon Islands and Vanuatu. Australian Journal of Entomology 40, 113-150.

Fletcher BS. 1998. Dacine fruit flies collected during the dry season in the lowland rainforest of Madang Province, Papua New Guinea (Diptera: Tephritidae). Australian Journal of Entomology 37, 315-318.

Gauch HGJ. 1982. Multivariate Analysis in Community Ecology. Cambridge University Press, Cambridge.

Hall R. 2001. Cenozoic reconstructions of SE Asia and the SW Pacific: changing patterns of land and sea. In: Faunal and Floral Migrations and Evolution in SE Asia and Australia (eds I Metcalfe) pp. 35-56. Balkema, Rotterdam.

Heads M. 2001a. Birds of paradise, biogeography and ecology in New Guinea: A review. Journal of Biogeography 28, 893-925.

Heads M. 2001b. Birds of paradise (Paradisaeidae) and bowerbirds (Ptilonorhynchidae): Regional levels of biodiversity and terrane tectonics in New Guinea. Journal of Zoology (London) 255, 331-339.

Heads M. 2001c. Regional patterns of biodiversity in New Guinea plants. Botanical Journal of the Linnean Society 136, 67-73.

Heads M. 2002a. Birds of paradise, vicariance biogeography and terrane tectonics in New Guinea. Journal of Biogeography 29, 261-283.

Heads M. 2002b. Regional patterns of biodiversity in New Guinea animals. Journal of Biogeography 29, 285-294. 
Leblanc L, Balagawi S, Mararuai A, Putulan D \& Clarke AR. 2001. Fruit Flies in Papua New Guinea. Pest Advisory Leaflet No. 37, Secretariat of the Pacific Community- Plant Protection Service, Fiji. pp.

Magurran AE. 1988. Ecological Diversity and its Measurement. Princeton University Press, Princeton, New Jersey.

Michaux B. 1994. Land movements and animal distributions in east Wallacea (eastern Indonesia, Papua New Guinea and Melanesia). Paleogeography, Paleoclimatology, Paleoecology 112, 323-343.

Michaux B \& White IM. 1999. Systematics and biogeography of southwest Pacific Bactrocera (Diptera: Tephritidae: Dacini). Palaeogeography, Paleoclimatology, Paleoecology 153, 337-351.

Miller Se, Cowie C, Polhemus D \& Eldredge L. 1993. Biodiversity and conservation of the nonmarine invertebrate fauna of Papua new Guinea. In: Papua new Guinea Conservation Needs Assessment, Vol. 2. A biodiversity analysis for Papua New Guinea (eds BM Beehler) pp. 227-325. Biodiversity Support Program, Washington, DC \& Department of Environment and Conservation, Boroko, PNG.

Parsons MJ. 1999. The Butterflies of Papua New Guinea: their systematics and biology. Academic Press, London.

Polhemus DA \& Polhemus JT. 1998. Assembling New Guinea: 40 million years of island arc accetion as indicated by the distributions of aquatic Heteroptera (Insecta). In: Biogeography and Geological Evolution of SE Asia (eds R Hall \& JD Holloway) pp. 327-340. Backhuys, Leiden.

Sigmaplot. 2002. Sigmaplot 2002 for Windows Version 8.0. SPSS Inc, Chicago.

Systat-Products. 1998. Systat Version 8.0. SPSS Inc., Chicago.

Waterhouse DF. 1997. The Major Invertebrate Pests and Weeds of Agriculture and Plantation Forestry in the Southern and Western Pacific. ACIAR, Canberra.

White IM \& Elson-Harris MM. 1992. Fruit flies of economic significance: Their identification and bionomics. C.A.B International in association with ACIAR, Wallingford, Oxon. 
White IM \& Evenhuis NL. 1999. New species and records of Indo-Australasian

Dacini (Diptera: Tephritidae). The Raffles Bulletin of Zoology 47, 487-540. 
Table 1: Number of dacine fruit fly species collected from provinces and major biogeographic regions of Papua New Guinea, plus the number of trapping sites per province serviced during the PNG Fruit Fly Project.

\begin{tabular}{lrrr}
\hline & $\begin{array}{r}\text { Number of } \\
\text { trap sites }\end{array}$ & $\begin{array}{r}\text { Number of } \\
\text { species }\end{array}$ & $\begin{array}{r}\text { Number of } \\
\text { species endemic to the } \\
\text { province }\end{array}$ \\
(percentage)
\end{tabular}


Table 2: Sorenson similarity indices and species overlap for ten provinces or province-pairs in Papua New Guinea. (The Sorenson index is a measure of similarity between two provinces, based on the number of shared species. Values range from one [100\% congruence in species] to zero [no species in common] [Magurran 1988]. Numbers in bold diagonally down the matrix are the number of species in the relevant province. $\mathrm{Sth} /$ Enga is combined data for the provinces of Southern Highlands and Enga; New Britain is combined data for the provinces of East and West New Britain; Sepik is combined data for the provinces of East and West Sepik)

\begin{tabular}{|c|c|c|c|c|c|c|c|c|c|c|c|}
\hline & $\begin{array}{c}\text { Western } \\
\text { Highlands }\end{array}$ & $\begin{array}{c}\text { Eastern } \\
\text { Highlands }\end{array}$ & Sth/Enga & Central & Morobe & Madang & Sepik & New Britain & $\begin{array}{l}\text { New } \\
\text { Ireland }\end{array}$ & $\begin{array}{l}\text { Bougain- } \\
\text { ville }\end{array}$ & \\
\hline $\begin{array}{l}\text { Western } \\
\text { Highlands }\end{array}$ & 54 & 0.67 & 0.59 & 0.57 & 0.55 & 0.58 & 0.60 & 0.29 & 0.24 & 0.15 & J \\
\hline $\begin{array}{l}\text { Eastern } \\
\text { Highlands }\end{array}$ & 33 & 45 & 0.63 & 0.53 & 0.52 & 0.6 & 0.61 & 0.21 & 0.19 & 0.08 & : \\
\hline Sth/Enga & 24 & 23 & 28 & 0.37 & 0.38 & 0.4 & 0.37 & 0.2 & 0.17 & 0.14 & 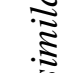 \\
\hline Central & 41 & 36 & 22 & 91 & 0.68 & 0.69 & 0.63 & 0.32 & 0.2 & 0.1 & $\frac{5}{2}$ \\
\hline Morobe & 46 & 41 & 27 & 69 & 113 & 0.68 & 0.62 & 0.33 & 0.24 & 0.11 & $\begin{array}{c}3 \\
0 \\
1\end{array}$ \\
\hline Madang & 36 & 35 & 20 & 56 & 63 & 71 & 0.83 & 0.34 & 0.26 & 0.12 & 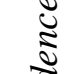 \\
\hline Sepik & 37 & 35 & 18 & 50 & 56 & 58 & 69 & 0.28 & 0.22 & 0.16 & : \\
\hline New Britain & 15 & 10 & 8 & 23 & 27 & 21 & 17 & 51 & 0.69 & 0.33 & $\tilde{5}$ \\
\hline New Ireland & 10 & 7 & 5 & 12 & 17 & 13 & 11 & 28 & 30 & 0.34 & $\frac{2}{2}$ \\
\hline Bougainville & 6 & 3 & 4 & 6 & 8 & 6 & 8 & 13 & 10 & 28 & \\
\hline & & & & Number & shared & pecies & & & & & \\
\hline
\end{tabular}





\section{FIGURE LEGENDS}

Figure 1: Political map of Papua New Guinea showing provinces.

Figure 2: Species accumulation curves for collections of dacine fruit flies

(Bactrocera and Dacus spp) in provinces of Papua New Guinea. Collections were run over different periods from mid 1998 through to late 2001 using modified Steiner traps baited with male lures (White \& Elson-Harris 1992). (Regressions are 3parameter logistic curves fitted using Sigmaplot Vs 8.0 [Sigmaplot 2002] and are used to assess if the accumulation curves had reached a point of inflection. For Manus and Chimbu logistic curves do not provide better fits of the data than do linear regressions. Sepik equals combined data for East and West Sepik Provinces, New Britain equals combined data for East and West New Britain Provinces.)

Figure 3: Dendogram illustrating the outcomes of a hierarchical, average linkage cluster analysis of 10 Papua New Guinean provinces based on dissimilarity in fruit fly fauna. Distance metric is Euclidean distance. (Sepik equals combined data for East and West Sepik Provinces; New Britain equals combined data for East and West New Britain Provinces; Sth/Enga equals combined data for Southern Highlands and Enga Provinces.) 


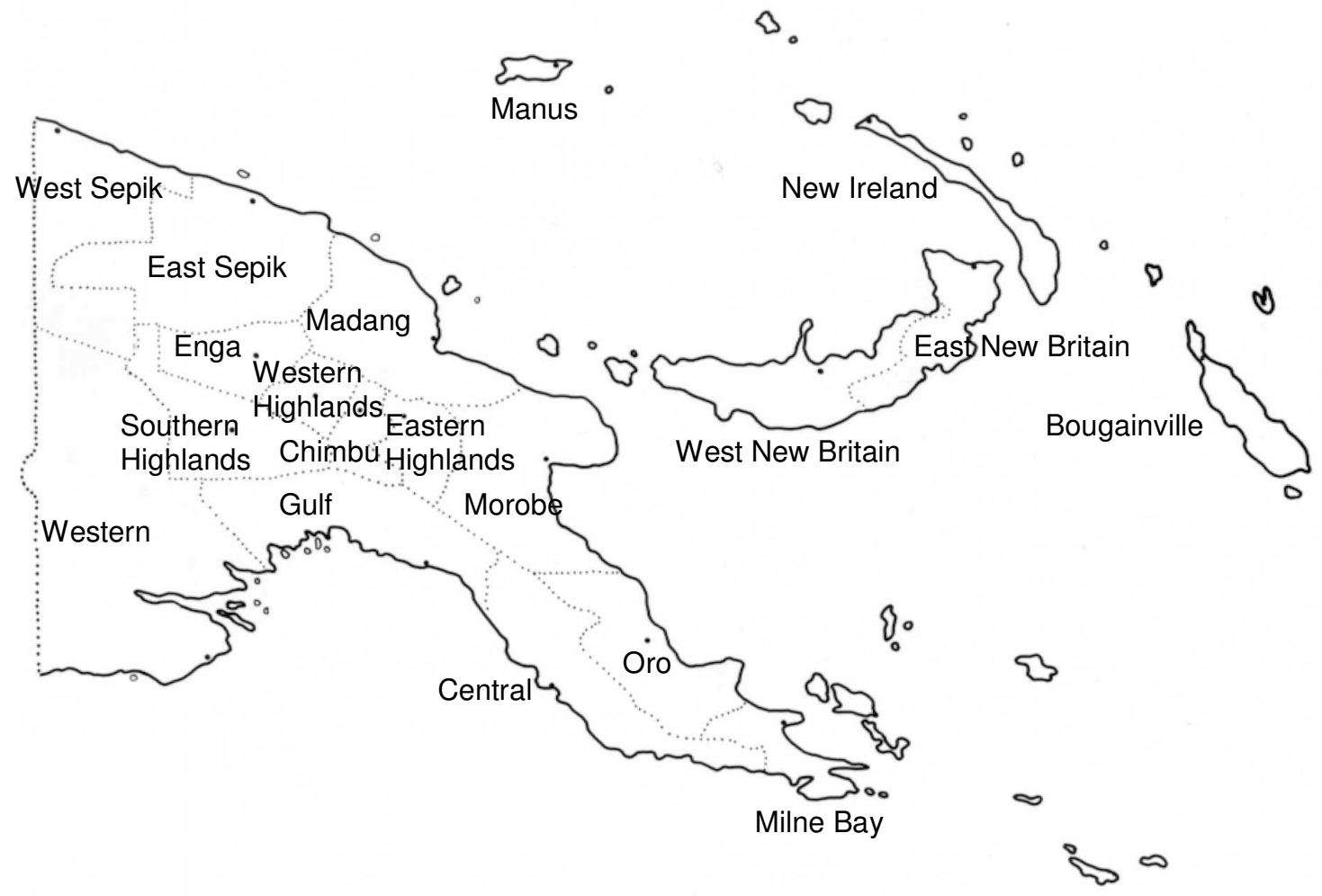

Figure 1 

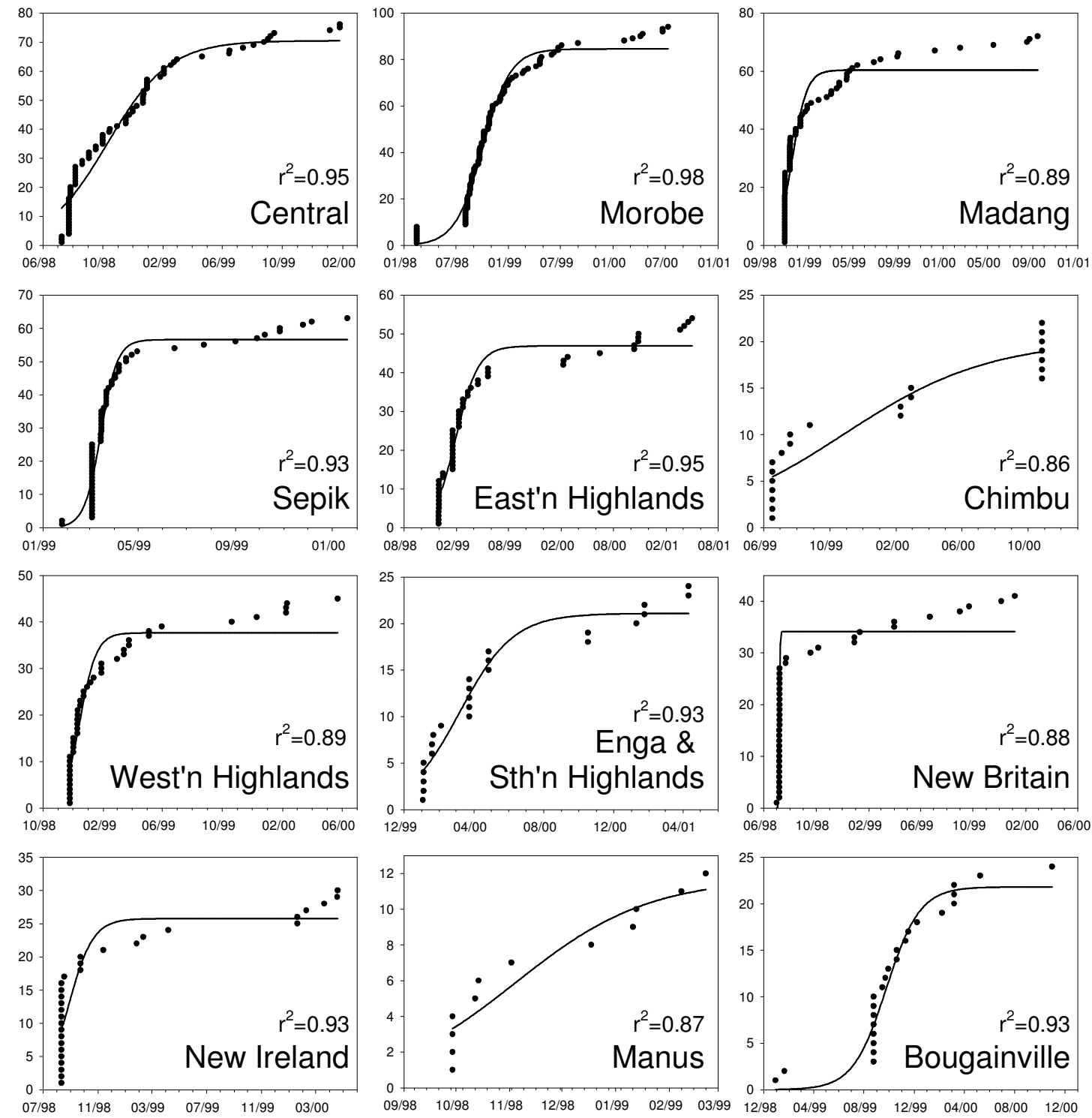

Figure 2 


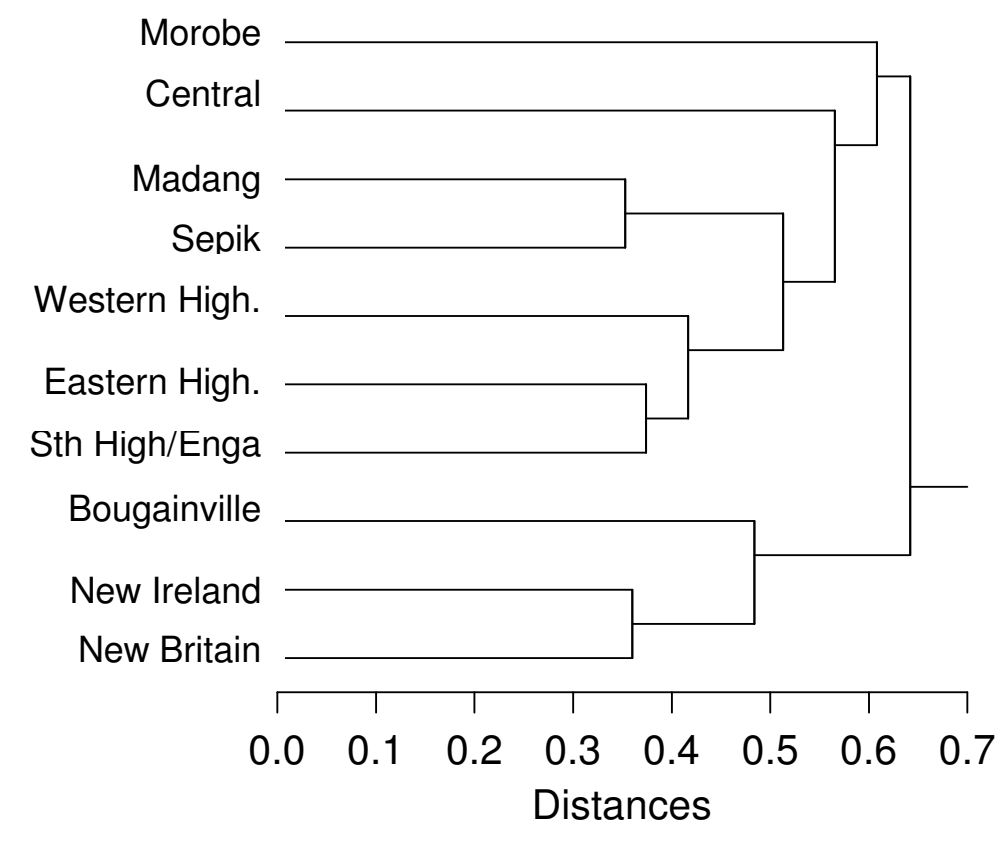

Figure 3 


\begin{tabular}{|c|c|c|c|c|c|c|c|c|c|c|c|c|c|c|c|c|c|c|}
\hline & 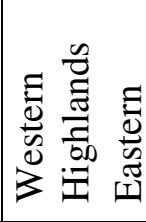 & & 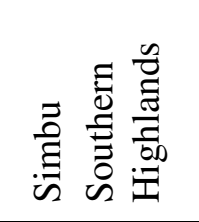 & $\begin{array}{l}5050 \\
5 \\
0\end{array}$ & & 訕 & 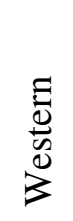 & 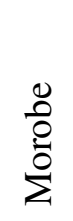 & 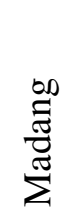 & 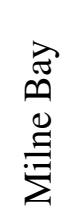 & ठั & 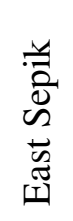 & 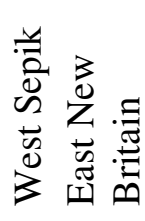 & & 吾 & 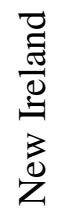 & 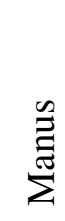 & 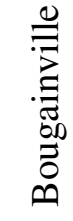 \\
\hline B. (Afrodacus) hypomelaina & 1 & & & & & & & 1 & & & & & & & & & & \\
\hline B. (A.) ochracea & & & & & 1 & & & & & & & & & & & & & \\
\hline B. (Bactrocera) abdofuscata & & & & & 1 & & & & & & & & & & & & & \\
\hline B. (B.) abdolonginqua & & & & & & & & & & & & & & 1 & & & & \\
\hline B. (B.) abdonigella & 1 & 1 & 1 & 1 & 1 & & & 1 & 1 & & & 1 & 1 & & & & & \\
\hline B. (B.) absidata & & & & & & & & 1 & & & & & & & & & & \\
\hline B. (B.) abundans & 1 & & & & 1 & & & 1 & & & & & & & & & & \\
\hline B. (B.) aemula & 1 & 1 & & & & & & 1 & 1 & & & & 1 & & & & & \\
\hline B. (B.) alyxiae & 1 & 1 & & & 1 & & & 1 & 1 & & & & 1 & & & & & \\
\hline B. (B.) ampla & & & & & & & & 1 & & & & & & 1 & & 1 & & \\
\hline B. (B.) anfracta & & 1 & & & 1 & & 1 & 1 & 1 & 1 & & 1 & 1 & & & & & \\
\hline B. (B.) angustifasciata & 1 & 1 & & & & & & & & & & & & 1 & & 1 & & \\
\hline B. (B.) anthracina & & & & & & & & 1 & & & & & & 1 & 1 & 1 & & \\
\hline B. (B.) assita & & & & 1 & & & & 1 & 1 & 1 & & & & & & & & \\
\hline B. (B.) aterrima & & & & & & & & & & & & & & 1 & & 1 & & 1 \\
\hline B. (B.) atramentata & & & & & & & & & 1 & & & & & 1 & 1 & 1 & 1 & \\
\hline B. (B.) atrilliniellata & & & & & 1 & & & 1 & & & & & & & & & & \\
\hline B. (B.) aurantiaca & & 1 & 1 & & 1 & & & 1 & 1 & & & 1 & & & & & & \\
\hline B. (B.) bancroftii & & 1 & & & 1 & & & 1 & 1 & & & 1 & 1 & & & & & \\
\hline B. (B.) biarcuata & & & & & & & & 1 & & & & & 1 & & & & & 1 \\
\hline B. (B.) breviaculeus & & 1 & 1 & & 1 & & 1 & 1 & 1 & & 1 & 1 & & & & & & \\
\hline
\end{tabular}


B. (B.) brevistriata

B. (B.) bryoniae

B. (B.) buloloensis

B. (B.) caliginosa

B. (B.) carbonaria

B. (B.) cheesmanae

B. (B.) cinnamea

B. (B.) circamusae

B. (B.) commina

B. (B.) confluens

$B$. (B.) congener

B. (B.) consectorata

B. (B.) contermina

B. (B.) contigua

B. (B.) curreyi

B. (B.) curvifera

B. (B.) dapsiles

B. (B.) daruensis

B. (B.) decumana

B. (B.) diallagma

B. (B.) dyscrita

B. (B.) endiandrae

B. (B.) enochra

B. (B.) epicharis

B. (B.) erubescentis

B. (B.) exspoliata

B. (B.) fergussoniensis

B. (B.) finitima

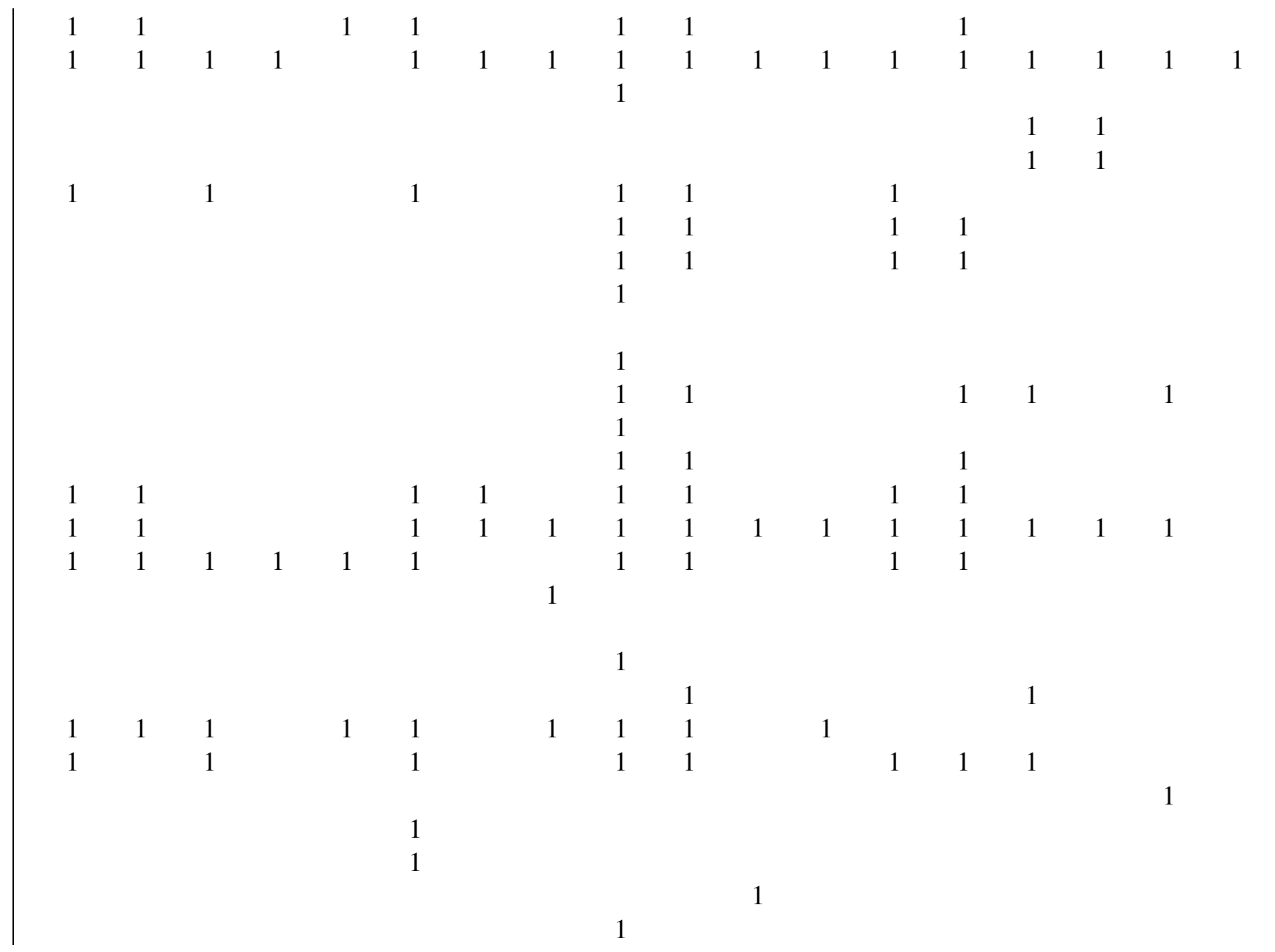


B. (B.) frauendfeldi

B. (B.) froggatti

B. (B.) fuliginus

B. (B.) fulvicauda

B. (B.) furfurosa

B. (B.) furvescens

B. (B.) furvilineata

B. (B.) inconstans

B. (B.) indecora

B. (B.) ismayi

B. (B.) kelaena

B. (B.) lampabilis

B. (B.) laticosta

B. (B.) latilineata

B. (B.) latissima

B. (B.) lineata

B. (B.) longicornis

B. (B.) mayi

$B$. (B.) melanogaster

$B$. (B.) mimulus

B. (B.) moluccensis

B. (B.) morobiensis

B. (B.) morula

B. (B.) musae

$B$. (B.) neocheesmanae

$B$. (B.) neohumeralis

$B$. (B.) neonigrita

B. (B.) nigella

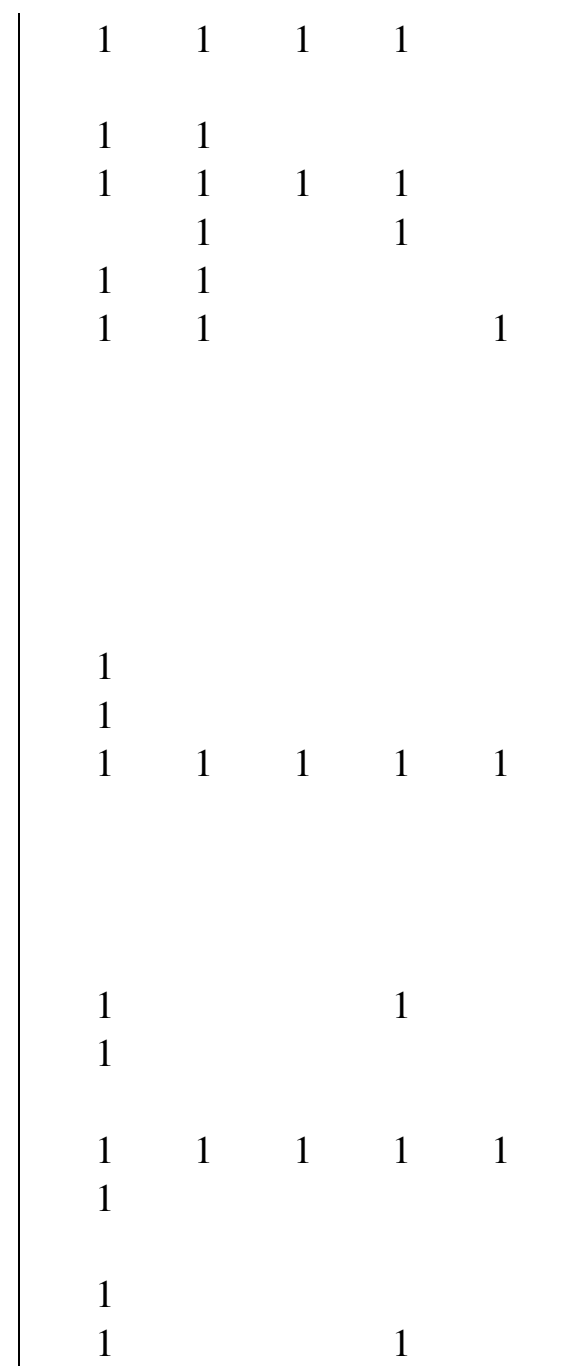

\begin{tabular}{|c|c|c|c|c|c|c|c|c|c|c|c|}
\hline \multirow[t]{9}{*}{1} & 1 & 1 & 1 & 1 & 1 & 1 & 1 & 1 & 1 & 1 & 1 \\
\hline & & 1 & 1 & & 1 & 1 & 1 & & & & \\
\hline & & 1 & 1 & 1 & 1 & 1 & 1 & & & & 1 \\
\hline & & 1 & & & & & & & & & \\
\hline & & 1 & & & & 1 & & & & & \\
\hline & & 1 & 1 & & & 1 & 1 & 1 & & & \\
\hline & & 1 & 1 & & & & & & & & \\
\hline & & & & & & & & 1 & 1 & 1 & \\
\hline & & & & & & & & 1 & & 1 & \\
\hline & & & & & & & & 1 & 1 & 1 & \\
\hline & & 1 & & & & & & & 1 & & \\
\hline & & 1 & & & & & & & & & \\
\hline & & 1 & 1 & & & 1 & & 1 & & & 1 \\
\hline \multirow[t]{4}{*}{1} & 1 & 1 & 1 & 1 & 1 & 1 & & & & & \\
\hline & & & & & & & & 1 & & 1 & \\
\hline & & 1 & & & & & & & & & \\
\hline & & 1 & 1 & & & & 1 & & & & \\
\hline \multirow[t]{3}{*}{1} & 1 & 1 & 1 & 1 & 1 & 1 & 1 & 1 & 1 & 1 & \\
\hline & & 1 & 1 & & & 1 & 1 & & & & \\
\hline & & & & & & & & 1 & & & \\
\hline \multirow[t]{4}{*}{1} & 1 & 1 & 1 & 1 & 1 & 1 & 1 & & & & \\
\hline & & & 1 & & & 1 & & & & & \\
\hline & & 1 & & & & & & & & & \\
\hline & & & & & & & 1 & 1 & 1 & 1 & \\
\hline
\end{tabular}


B. (B.) nigrescens

B. (B.) nigrescentis

B. (B.) nigrovittata

B. (B.) obfuscata

B. (B.) oblineata

B. (B.) obliqua

B. (B.) ochromarginis

B. (B.) papayae

B. (B.) paramusae

B. (B.) peninsularis

B. (B.) pepisalae

B. (B.) phaea

B. (B.) picea

B. (B.) pisinna

B. (B.) popondettiensis

B. (B.) prolixa

B. (B.) propedistincta

B. (B.) pseudodistincta

B. (B.) quadrata

B. (B.) quasisilvicola

$B$. (B.) reclinata

$B$. (B.) recurrens

B. (B.) redunca

$B$. (B.) repanda

B. (B.) resima

$B$. (B.) retrorsa

B. (B.) rhabdota

B. (B.) robertsi

1

1

1

111


B. (B.) rutila

$B$. (B.) seguyi

B. (B.) simulata

$B$. (B.) terminaliae

B. (B.) thistletoni

B. (B.) tinomiscii

B. (B.) trifaria

B. (B.) trivialis

B. (B.) turneri

B. (B.) umbrosa

B. (B.) unilineata

B. (B.) unistriata

B. (B.) ustulata

B. (B.) vulgaris

B. (Bulladacus) aceraglans

B. (Bu.) aceromata

B. (Bu.) bullata

B. (Bu.) eximia

B. (Bu.) penefurva

B. (Gymnodacus) calophylli

B. (G.) hastigerina

B. (G.) petila

B. (Heminotodacus)

dissidens

B. (Hemiparatridacus)

abdoaurantiaca

B. (Hemisurstylus)

melanoscutata

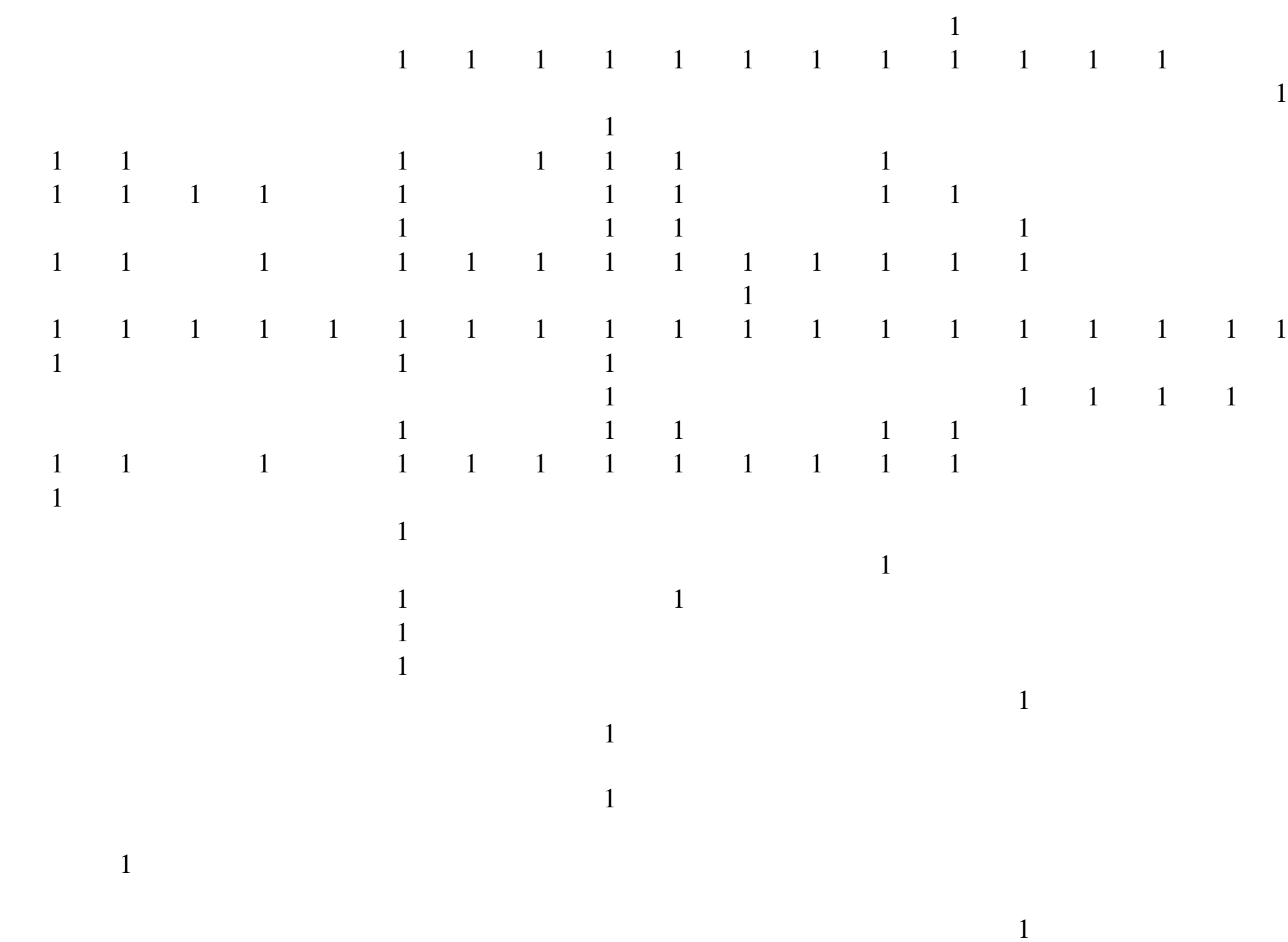


B. (Hemizeugodacus)

abdomininigra

1

B. (Hemiz.) buinensis

B. (Heterodaculus) fuscalata

B. (Het.) mesonotochra

B. (Het.) visenda

B. (Melanodacus) satanellus

B. (Niuginidacus) singularis

B. (Papuodacus)

neopallescentis

B. (Paradacus) aurantiventer

B. (Parad.) citroides

B. (Parad.) decipiens

B. (Paratridacus) alampeta

B. (Parat.) atrisetosa

B. (Parat.) coracina

B. (Parat.) expandens

B. (Parat.) mesonotaitha

B. (Parat.) unichromata

B. (Queenslandicus) exigua

B. (Semicallantra) aquila

B. (Se.) memnonia

B. (Se.) nigricula

B. (Sinodacus)

abdopallescens

B. (Si.) angusticostata

B. (Si.) buvittata

B. (Si.) emarginata

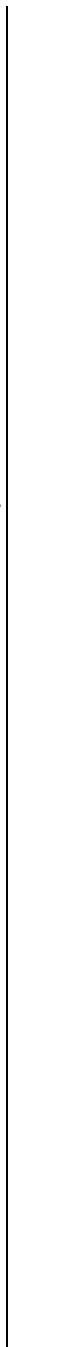

$\begin{array}{llll}1 & & & \\ 1 & 1 & 1 \\ 1 & & \\ 1 & & & \\ 1 & & & \\ 1 & & \end{array}$

1

1

1 
B. (Si.) paulula

B. (Si.) sepikae

B. (Si.) strigifinis

B. (Si.) surrufula

B. (Si.) triangularis

B. (Si.) univittata

B. (Tetradacus) neopagdeni

B. (Trypetidacus) invisitata

B. (Zeugodacus)

abdoangusta

B. (Z.) amoena

B. (Z.) anchitrichota

B. (Z.) brachus

B. (Z.) chorista

B. (Z.) cucurbitae

B. (Z.) curta

B. (Z.) daula

B. (Z.) macrovittata

$B$. (Z.) reflexa

B. (Z.) sandaracina

B. (Z.) trichota

B. (Z.) ubiquita

B. (Z.) unilateralis

D. (Callantra) axanthinus

D. (C.) axanus

D. (C.) capillaris

D. (C.) discors

D. (C.) impar

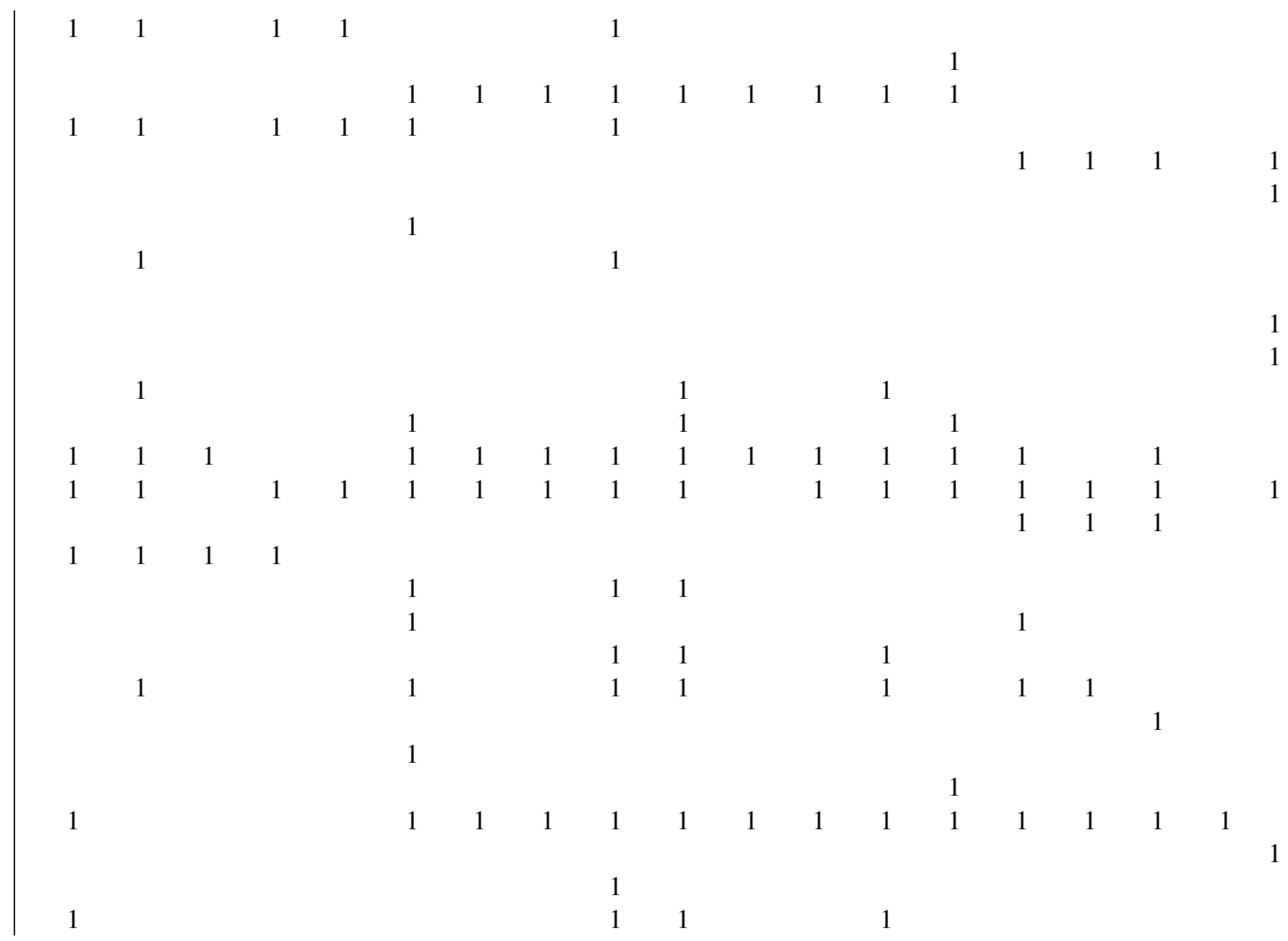




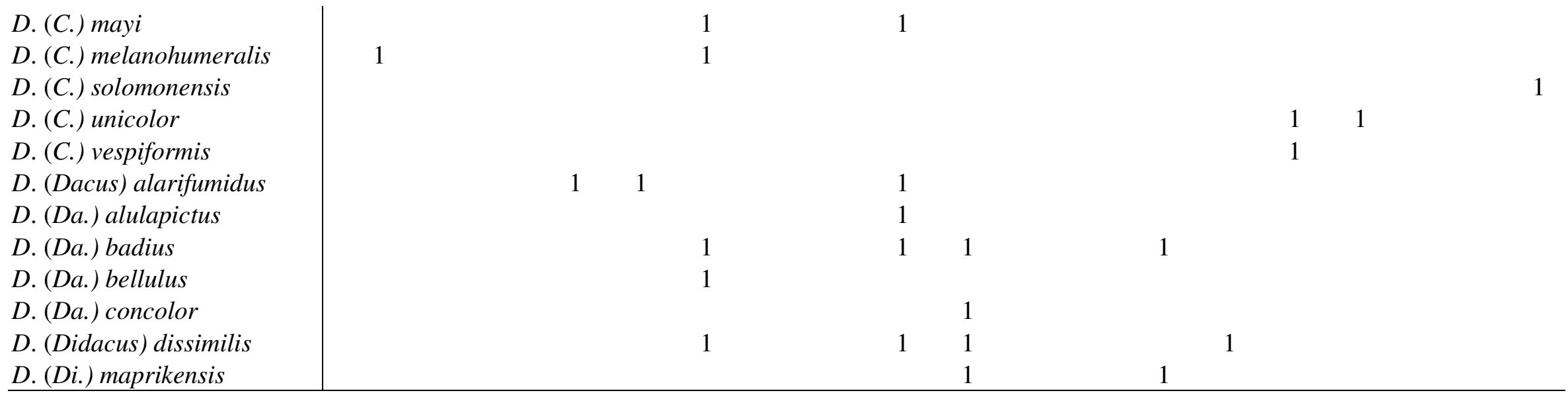

